\title{
Note
}

(C2018 The Society of Rheology, Japan

\section{Transient Variation of Dynamic Viscoelasticity of Uniaxially Stretched Glassy Poly(methyl methacrylate) after Abrupt Change of Tensile Rate}

\author{
Shin’ya Yoshioka ${ }^{\dagger}$ and Hiroaki Matsumoto \\ Department of Mechanical and Physical Engineering, Graduate School of Engineering, Osaka City University, \\ Sugimoto, Sumiyosi-ku, Osaka 558-8585
}

\begin{abstract}
Variation of dynamic shear modulus, $G^{*}=G^{\prime}+i G^{\prime \prime}$, was measured for glassy poly(methyl methacrylate) (PMMA) during uniaxial stretching processes where the tensile rate changed stepwise. Under the condition of constant-rate stretching, it is known that $G^{\prime}$ and $G^{\prime \prime}$ gradually change to their steady values in the post-yield range of strain, and that the change occurs strongly at a higher tensile rate, indicating strain-induced changes in glassy structures. After a change of tensile rate, $G^{\prime}$ as well as $G^{\prime \prime}$ varied monotonously from their values at the initial tensile rate to those at the final rate in a strain range where the uniaxial stress $\sigma$ exhibited transient responses to the tensile rate change. The observed variation of $G^{\prime}$ and $G^{\prime \prime}$ simply indicates that, after an abrupt change of tensile rate, structures of the glass successively change from those corresponding to initial tensile rate to final rate.
\end{abstract}

Key Words: Poly(methyl methacrylate) (PMMA) / Uniaxial stretching / Tensile rate change / Dynamic viscoelasticity / Change in glassy structures

\section{延伸速度の急変を受けるガラス状ポリメタクリル酸メチルの動的粘弾性変化}

\author{
吉岡 真弥，松本 博昭
}

(原稿受理：2018 年 5 月 15 日)

\section{1. 緒 言}

ガラス状高分子が大変形下で示す非線形粘弾性はガラスの 凝集構造の変化がその本質的原因であると考えられるように なってきた。 ガラスは熱力学的非平衡状態にあるため自発的 に構造緩和を生じ，それに伴って系の緩和時間は増大する。 一方, 大きな力学的刺激はガラスの構造緩和を反転させ, そ の結果としてガラスの緩和時間が減少する。これらの二つの 効果の競争により非線形緩和時間が定まるという考え方であ る.クリープ応力の負荷あるいは等速変形の印加といった静 的変形条件下では, 力学刺激による構造緩和の反転と構造緩 和の進行が釣り合う状態へと向かってガラス構造は不安定化 し, 非線形緩和時間は変形の進行とともに急激に低下して変 形条件に応じた定常值に至ってガラスは定常流動することに なる。ガラス構造が高度に不安定化するほどその構造緩和は より早くなるためである.

変形の途中でひずみ速度が階段状に変化するひずみ速度プ ログラムを用いてガラス状高分子を変形させると, 変速後の 応力 $\sigma$ は元のひずみ速度における $\sigma$ ひずみ $\varepsilon$ 関係から逸脱 して過渡応答を示したのち, 変速後のひずみ速度における等 速変形下の $\sigma^{-} \varepsilon$ 曲線にひずみ軟化後の流動領域において一

$\dagger$ E-mail : yoshioka@eng.osaka-cu.ac.jp

大阪市立大学大学院工学研究科機械物理系専攻

于 558-8585 大阪市住吉区杉本 3-3-138
致する ${ }^{1-3)}$. この挙動は, 変速後の非線形緩和特性が最終的に 変速後のひずみ速度のみに対応して定まる特性となること, すなわち，等速変形過程においてひずみ軟化後に現れる流動 が確かに定常流動であることを示している，筆者らは，ひず み軟化後に現れる定常流動に関する非線形粘度解析結果から 定常流動しているガラスの構造は高度に不安定化しているこ と，および，高ひずみ速度条件ほどこの不安定の程度がより 高いことを報告してきた ${ }^{1,2,4)}$. 単純な非線形単一緩和モデル を用いて等速変形下の $\sigma-\varepsilon$ 関係を解析すると, 等速変形の 過程において非線形単一緩和時間, $\tau_{\mathrm{SS}}$, は急激に低下して ひずみ速度にほぼ反比例する定常值に至ることが示せる ${ }^{5-8)}$. この $\tau_{\mathrm{SS}}$ とひずみ速度の反比例関係は力学的刺激が強いほど ガラス構造が高度に不安定化することに対応すると理解でき る。ポリメタクリル酸メチル (PMMA) のクリープ過程お よび等速変形過程に関して Ediger ${ }^{9,10)}$ が光学的手法で実験 的に求めたセグメント緩和時間 $\tau_{\mathrm{c}}$ についても, 変形の進行 とともに $\tau_{\mathrm{c}}$ が桁で低下して定常值へと至ること，および， $\tau_{\mathrm{c}}$ の定常值はその時点のひずみ速度におよそ反比例することが 示されている. ガラスの構造緩和と力学的刺激によるその反 転の競争によって非線形緩和時間が定まるという物理描像を 導入したモデルがEdiger らのセグメント緩和の実験データ を良好に再現することも報告されている吕12). しかしながら， ガラスの構造変化および非線形流動の具体的機構の詳細は依 然としてよくわかっていない.

さて, 筆者らは最近, 変形の途中でひずみ速度が階段状に 
変化する一軸圧縮過程における非線形緩和時間 $\tau_{\mathrm{SS}}$ の変化を 上述の非線形単一緩和模型を用いて解析した ${ }^{13)}$. その結果, ひずみ速度を階段状に低下（減速）させた場合， $\tau_{\mathrm{SS}}$ は初期 速度に対応した值から減速後の定常值へと向かって連続的に 増加するのに対して, 増速した場合には増速直後に極めて高 い值へと一度不連続に飛び移ってから増速前よりも低い増速 後の定常值へと急激に減少することがわかった. 増速した瞬 間にガラス構造が不連続に変化するとは考えられないので, 変速後の緩和特性変化とその意味についてはさらに詳しく調 べる必要があることになる

そこで本研究では，ひずみ速度の階段状の変化がガラス状 高分子の非線形緩和特性に及ぼす影響について検討すること を目的として，一軸延伸を受ける試験片に微小变位の強制ね じり振動を重ね合わせる方法を用いて, ひずみ速度が階段状 に変化する延伸過程におけるPMMAの動的粘弾性の変化を 測定した，等速延伸過程における動的粘弾性変化は, 後述す るように, 変形条件に対応した不安定構造へと向かってガラ ス構造が変化するというモデルで解釈できることがわかって いる ${ }^{14-16)}$.

\section{2. 実験方法}

試料には市販の厚さ $5 \mathrm{~mm}$ の PMMA キャストシート（アク リライト L, 三菱レイヨン製) を用いた。 昇温速度 $1{ }^{\circ} \mathrm{C} /$ 分 の DSC 測定により求めた試料のガラス転移温度 $T_{\mathrm{g}}$ は $110^{\circ} \mathrm{C}$ であった。この試料シートから $5 \mathrm{~mm} \times 5 \mathrm{~mm} \times 30 \mathrm{~mm}$ の平 行試験部を持つ引張試験片を機械加工した。試料の熱的およ び機械的履歴を消去するとともに, 試料ガラスを準平衡状態 とすることを目的として, 試験片は $T_{\mathrm{g}}$ よりも高温の $130^{\circ} \mathrm{C}$ に 2 時間保持してから毎時 $3{ }^{\circ} \mathrm{C}$ の冷却速度で徐冷する熱処 理の後実験に供した。

一軸延伸はインストロン型の材料試験機で行った。延伸に は 2 段階の公称ひずみ速度 $\dot{\varepsilon}_{n}=8.3 \times 10^{-4} \mathrm{~s}^{-1}$ および $8.3 \times$ $10^{-6} \mathrm{~s}^{-1}$ を用いた。 一方の速度で延伸を開始後, 公称ひずみ $\varepsilon_{n}=0.02 \sim 0.12$ の範囲においてもう一方のひずみ速度へと階 段状に変化させた。延伸温度は $90^{\circ} \mathrm{C}$ とした. 真応力 $\sigma$ は試 験部の均一かつ体積一定の変形を仮定して求めた. このため, 試験部がくびれていないことを目視で確認できた実験のデー タのみを採用した.

延伸過程における動的粘弾性の同時測定は材料試験機に自 作の動的粘弾性測定装置を取り付けて行った。この装置は延 伸中の試験片上端をねじりに対して固定し, 試験片下端に延 伸軸を中心とした強制ねじり振動を正弦波で加える構造と なっている. 強制ねじり振動の角変位振幅は動的粘弾性応答 が線形の範囲となる $0.016 \mathrm{rad}$ とし, 測定周波数 $f$ は $1.93 \mathrm{~Hz}$ とした。この条件による強制ねじり振動の重畳が一軸延伸の 応力ーひずみ関係を乱さないことを確認した，入力ひずみ振 動および応答トルク振動のデータから, 貯蔵せん断弾性率 $G^{\prime}$ および損失せん断弾性率 $G^{\prime \prime}$ を公称ひずみ $\varepsilon_{\mathrm{n}}$ の関数とし て求めた。 これらの計算に際しても体積一定の均一変形を仮 定した。

\section{3. 実験結果}

階段状に増速する延伸過程における真応力 $\sigma$, 貯蔵せん断

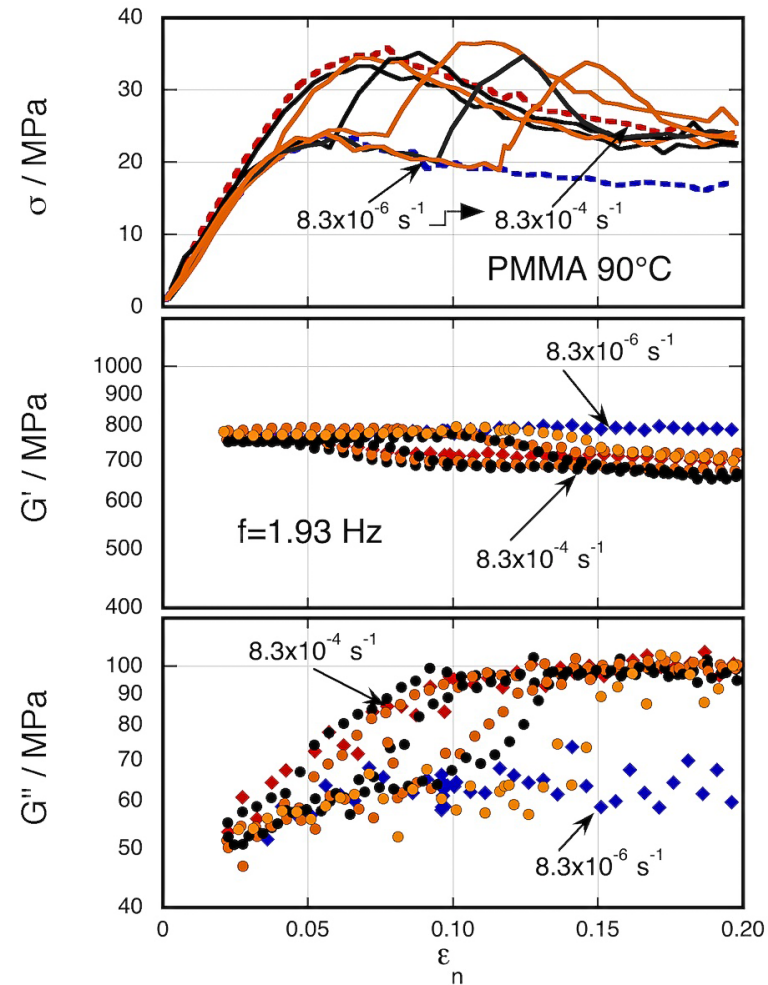

Fig. 1 True stress $\sigma$, storage shear modulus $G^{\prime}$ and loss shear modulus $G^{\prime \prime}$ plotted against nominal strain $\varepsilon_{\mathrm{n}}$ observed for stretching processes during which tensile rate increased stepwise. Thick dashed lines in the upper panel and diamonds in the middle and lower panels are the results of constant-speed experiments.

弾性率 $G^{\prime}$ および損失せん断弾性率 $G^{\prime \prime}$ の公称ひずみ $\varepsilon_{\mathrm{n}}$ に対 する変化を，増速前後のひずみ速度 $\dot{\varepsilon}_{n}$ を用いて等速延伸し た場合の結果とともに Fig. 1 に示した。中段パネルの $G^{\prime} お$ よび下段パネルの $G^{\prime \prime}$ を $\varepsilon_{\mathrm{n}}=0.02$ 程度以降のみ描いたのは, $\varepsilon_{\mathrm{n}}=0.02$ 程度までの軸荷重が低い領域ではねじりの軸が安定 せず正確な值が測定できなかったためである。

等速延伸時の応答をまず見ておく，等速延伸時の $\sigma-\varepsilon_{\mathrm{n}}$ 曲 線は太い破線で示した（上段パネル）。本測定の $\sigma$ にはやや

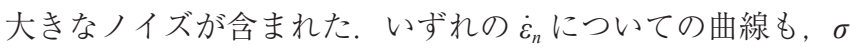
は延伸開始直後に直線的に立ち上がった後, 降伏点後に緩や かにひずみ軟化し, 延伸終了時の $\varepsilon_{\mathrm{n}}=0.20$ 付近ではおよそ一 定の值となった，高ひずみ速度条件ほど $\sigma$ が常に高い值を示 したことも併せて， $\sigma-\varepsilon_{\mathrm{n}}$ 曲線はガラス状高分子の典型的な 非線形応答であった，等速延伸時の $G^{\prime}$ は印で示した。高 ひずみ速度条件の $\dot{\varepsilon}_{n}=8.3 \times 10^{-4} \mathrm{~s}^{-1}$ における $G^{\prime}$ は $G^{\prime}-\varepsilon_{\mathrm{n}}$ 関 係のいちばん下側の包絡線の位置を通った。すなわち, 低 $\varepsilon_{\mathrm{n}}$ 領域で一定值を示した後, $\varepsilon_{\mathrm{n}}=0.03 \sim 0.10$ 付近のひずみ域に おいて緩やかに低下してから高 $\varepsilon_{\mathrm{n}}$ 域でほぼ一定の低い值と なった。 もう一方の $\dot{\varepsilon}_{n}=8.3 \times 10^{-6} \mathrm{~s}^{-1}$ では $G^{\prime}$ は変形過程を 通じてほぼ一定のままであった。低 $\varepsilon_{\mathrm{n}}$ 領域の $G^{\prime}$ は $\dot{\varepsilon}_{n}$ に依存 しない線形応答であることがわかる．等速延伸時の $G^{\prime \prime} も$ 印で示した，バラツキが大きいが，いちばん上を通る包絡線 およびいちばん下を通る包絡線がそれぞれ高速および低速条 件での結果である。等速延伸時の $G^{\prime \prime}-\varepsilon_{\mathrm{n}}$ 関係は低 $\varepsilon_{\mathrm{n}}$ 領域に おける $\dot{\varepsilon}_{n}$ に依存しない低い值から $\varepsilon_{\mathrm{n}}=0.10$ 付近以降におけ る高 $\dot{\varepsilon}_{n}$ ほど高い一定值へと緩やかに増加した，等速延伸に よる $G^{\prime}$ の低下および $G^{\prime \prime}$ の増加が (1) 降伏点に達する前の 低ひずみで始まって降伏点を十分に超える高ひずみにかけて 


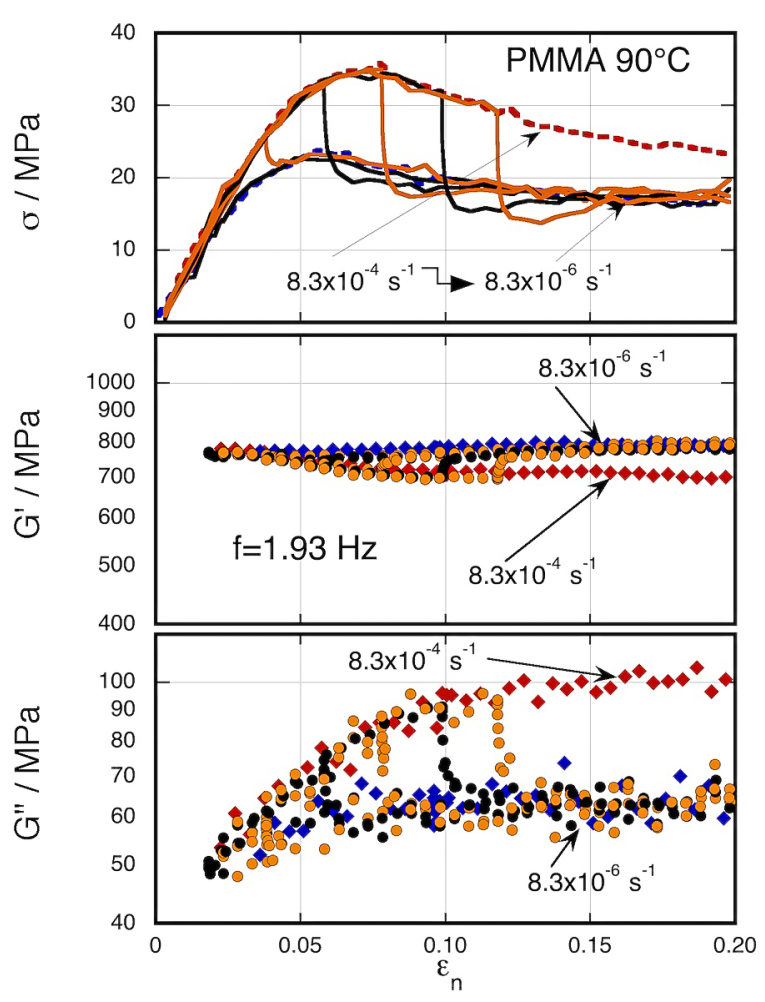

Fig. 2 Quantities $\sigma, G^{\prime}$ and $G^{\prime \prime}$ plotted against $\varepsilon_{\mathrm{n}}$ observed for stretching processes during which tensile rate decreased stepwise. Symbols have the same meaning as those in Fig. 1.

生じること，および，（2）延伸に伴うこれらの変化が高 $\dot{\varepsilon}_{n}$ 条件ほど大きいこと, はいずれも既報 ${ }^{14-16)}$ の特徴を再現して いる。

増速後の $\sigma$ (実線) は, 増速後のひずみ速度 $\dot{\varepsilon}_{n}=8.3 \times$ $10^{-4} \mathrm{~s}^{-1}$ で等速延伸した際の初期弾性率と同程度の傾きでまず 立ち上がった後, $\dot{\varepsilon}_{n}=8.3 \times 10^{-4} \mathrm{~s}^{-1}$ における等速の $\sigma-\varepsilon_{\mathrm{n}}$ 曲 線に対してオーバーシュートしてから高ひずみ域において同 一のほぼ一定の值に収れんした。このオーバーシュートは降 伏点以降の $\varepsilon_{\mathrm{n}}$ において増速した場合に顕著に認められた。 増速実験時の $G^{\prime}$ および $G^{\prime \prime}$ は図中に○印で描いた。図から 明らかなように, $\sigma$ が過渡応答を示している $\varepsilon_{\mathrm{n}}$ 領域において $G^{\prime}$ および $G^{\prime \prime}$ ともに増速前の值から増速後の $\dot{\varepsilon}_{n}=8.3 \times$ $10^{-4} \mathrm{~s}^{-1}$ での等速延伸時の值へと連続的に移り変わった。

減速実験の結果を Fig. 2 に示す。減速前後の $\dot{\varepsilon}_{n}$ における 等速変形の結果はFig. 1 に示したものと同一であり, 破線お よびくで示した，実線および○印が減速実験の結果である。 $\sigma$ は降伏点付近以降で減速した場合に減速後のひずみ速度 $\dot{\varepsilon}_{n}=8.3 \times 10^{-6} \mathrm{~s}^{-1}$ における $\sigma-\varepsilon_{\mathrm{n}}$ 曲線に対してアンダーシュー 卜を示した後収れんした。減速した場合にも， $G^{\prime}$ およ゙ $G^{\prime \prime}$ は減速前の值から減速後の $\dot{\varepsilon}_{n}=8.3 \times 10^{-6} \mathrm{~s}^{-1}$ における等速延 伸時の值へと連続的に移り変わった。 この変化は $\sigma$ の過渡応 答と同程度もしくはやや短い $\varepsilon_{\mathrm{n}}$ の範囲で生じた。

\section{4. 考 察}

等速延伸過程において $G^{\prime}$ が未変形時よりも低い一定値へ と低下すると同時に $G^{\prime \prime}$ が高い一定值へと増加する変化, そ してその変化が高ひずみ速度ほど大きく現れることは, 等速 変形に伴うガラス構造の不安定化を反映していると理解でき
る ${ }^{14-16)}$ ，変速後の $G^{\prime}$ および $G^{\prime \prime}$ はいずれも，ひずみ速度の増 加あるいは減少によらず，変速前の值から変速後の速度にお ける等速延伸時の值へと単調に変化した，この結果は，変形 途中で $\dot{\varepsilon}_{n}$ を変化させるとガラス構造は変速前の $\dot{\varepsilon}_{n}$ に対応し た構造から変速後の $\dot{\varepsilon}_{n} に$ 対応した構造へと連続的に変化す ることを示している。すすおち，今回測定した線形粘弾性特 性の変化は, 大変形下のガラス構造が力学刺激による構造緩 和の反転と構造緩和の進行の競争現象によって変化し, 静的 変形条件では変形条件に応じたガラス構造へと最終的に至る という理解を支持している。

\section{5. 結 言}

変形の途中でひずみ速度を階段状に変化させる延伸を PMMA に加え, その過程における一軸応力 $\sigma$ と線形動的粘 弾性の変化を測定した。変速後の $G^{\prime}$ および $G^{\prime \prime}$ は， $\sigma$ が過渡 応答を示すひずみ領域において，いずれも変速前のひずみ速 度 $\dot{\varepsilon}_{n}$ における值から変速後の $\dot{\varepsilon}_{n}$ に対応した值へと単調に連 続的に変化した。 この結果は, 変形途中で $\dot{\varepsilon}_{n}$ を変化させる とガラス構造は変速前の $\dot{\varepsilon}_{n}$ に対応した構造から変速後の $\dot{\varepsilon}_{n}$ に対応した構造へと連続的に変化することを意味している。

\section{REFERENCES}

1) Nanzai Y, Prog Polym Sci, 18, 437 (1993).

2) Nanzai Y, Nihon Reoroji Gakkaishi (J Soc Rheol Jpn), 20, 4 (1992).

3) Yoshioka S, Kato S, Nihon Reoroji Gakkaishi (J Soc Rheol Jpn), 45, 79 (2017).

4) Nanzai Y, Kimura Y, Yoshioka S, Nihon Reoroji Gakkaishi (J Soc Rheol Jpn), 28, 289 (1997).

5) Yoshioka S, Fujimoto H, Nanzai Y, Kobunshi Ronbunshu, 54, 434 (1997).

6) Yoshioka S, Kanda N, Nanzai Y, Kobunshi Ronbunshu, 61, 295 (2004).

7) Yoshioka S, Iwamoto M, Zairyo (J Soc Mat Sci Jpn), 60, 51 (2011).

8) Yoshioka S, Masuda R, Zairyo (J Soc Mat Sci Jpn), 64, 52 (2015).

9) Bending B, Christison K, Ricci J, Ediger MD, Macromolecules, 47, 800 (2014).

10) Lee H-N, Paeng K, Swallen SF, Ediger MD, J Chem Phys, 128, 134902 (2008).

11) Fielding SM, Larson RG, Cates ME, Phys Rev Lett, 108, 048301 (2012).

12) Mizuno H, Yamamoto R, Eur Phys Chem, B, 118, 5608 (2012).

13) Yoshioka S, Masuda M, Nihon Reoroji Gakkaishi (J Soc Rheol Jpn), 45, 235 (2017).

14) Yoshioka S, Usada H, Nanzai Y, J Non-Crystalline Solids, 172-174, 765 (1994).

15) Yoshioka S, Tachibana H, Nanzai Y, Zairyo (J Soc Mat Sci Jpn), 49, 1257 (2000).

16) Yoshioka S, Toyoda M, Iwamoto M, Nihon Reoroji Gakkaishi (J Soc Rheol Jpn), 44, 81 (2016). 